\title{
排水性舗装のミクロテクスチャの 評価方法の提案
}

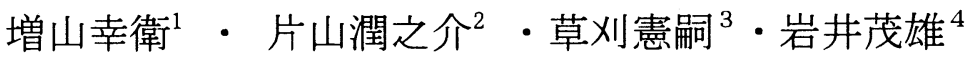

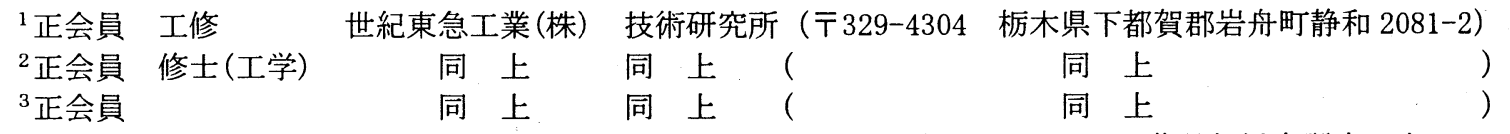

${ }^{4}$ 正会員 博士 (工学) 日本大学理工学部社会交通工学科 教授（テ274-8501 千葉県船橋市習志野台7-24-1)

\begin{abstract}
排水性舗装の騒音低減効果の回復を目的として行った表面処理の試験施工において, 表面が滑らかになる につれ，騒音レベルが大きくなる現象が見られた．粗骨材は変動しないと仮定し，アスファルトモルタルの すり減りと空隙つまり状態に基づき，ミクロテクスチャによる排水性舗装表面を評価できる新たな方法を提 案した．機能回復に伴うテクスチャの変化の解析から, 粗骨材の不動区間の存在がみいだせ, ミクロテクス チャの変化を評価できることの可能性および，ミクロテクスチャの変化と動的摩擦係数との間に高い相関の あることが確認できた。このことから，表面が滑らかになるにつれ，騒音レベルが大きくなる現象は，接地 面でのタイヤトレッドブロックのStick-Slipによるものであることが推定できた.
\end{abstract}

Key Words : porous pavement function recovery works, micro-texture, dynamic friction coefficient, tire/road noise, stick-slip

\section{1.はじめに}

排水性舗装は，その空隙の多さによって騷音低減効果 を有することが知られている，同時に，その低減効果は 供用期間とともに低下寸ることから，機能の維持，また は回復が大きな課題となっている，そのため筆者らは， 空隙つまり物（以下，つまり物）を除去することによっ て, 機能回復を行うための手法についての研究を行って きた

しかしつまり物を除去しても，騒音の低減効果が回復 しない事例が報告されるようになってきている ${ }^{2) . こ の ~}$ 原因は，舖装表面のテクスチャが関係していると考え， 2.研究の目的に示したように, 表面処理による機能回復 手法に関する研究を行い，一定の成果を得た.

このとき，テクスチャの評価は MPD(S) $)^{3)}$ (MPD :

Mean Profile Depth を $10 \mathrm{~cm} \times 100 \mathrm{~cm}$ の範囲で 110 ヶを平均 化した值）によって行っていたが，MPD(S)が小さくな る程に騒音レベルが大きくなる現象が生じた．また，現 在提案されている他の評価方法についても, MPD(S) と の相関が高いことから，同椂の傾向が示される.

この現象は，従来の表面が粗くなるにつれ，騷音レべ ルが大きくなるといわれている傾向 ${ }^{4)}$ とは異なる．その 原因について，MPD（以下，MPD と記す場合は MPD(S)
を含む）は基長区間を平均することから，表面処理のよ うに微細な変化の結果を評価しきれないものと推定した。 そのため, 骨材の形状に着目し, ミクロテクスチャを考 慮した仮の基準点を設定する評価方法を見出したので, 本手法とその評価方法に基づく表面処理の効果について 報告する.

\section{2. 研究の目的}

筆者らは，排水性舗装の騒音低减効果の回復を目的と して,つまり物の除去や, 表面処理などによる機能回復 作業の開発を進めてきた. 排水性舗装のテクスチャの変 化は，表面のアスファルトモルタル分（以下，アスモ ル）の消失や摩耗による変化，つまりやつぶれによる空 隙の変化等によると考えられる. そしてこれらの変化は, 舗装の騒音低減効果に大きく関係しており，MPD など と正の相関がある ${ }^{4)}$ とれている.

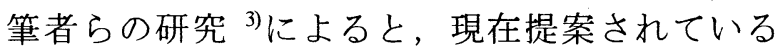

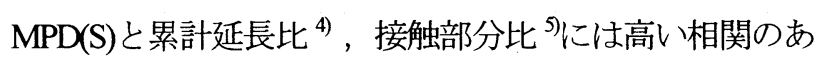
る事が確認できたことから，この3 手法は，多少の違い はあるものの，本質的には同じような評価方法と考えら れた ${ }^{3)}$.

しかし表面処理を行った路面において, MPD(S)と夕 
イヤ/路面騒音レベルの間に，高い負の相関が生じた． そのためタイヤ騒音の発生メカニズムを考える上で, 微 少な表面のテクスチャの変化については MPD よりもっ とミクロテクスチャに注目した評価が必要と考え，以下 を目的に新たな評価方法についての研究を行った.

・ ミクロテクスチャの変化を評価できること

・変化した部分を特定する事ができること

・機能回復効果を評価できること

\section{3.つまり物の除去ならびに表面処理による騒音 低減効果の回復効果}

排水性舗装の騷音低減効果の回復効果として，つまり 物の除去による方法 ${ }^{2}$ は示されているものの, 表面処理 による方法は示されていない. そのため現道において, つまり物の除去と表面処理についての検証を行った.

\section{(1) 施工概要}

試験は国道 10 号, 宮崎県新富町, 宮崎市の 2 路線と, 国道 6 号水戸市の各 1 路線において，つまり物の除去と 表面処理による回復効果と, 経時変化について検討を行 った.

測定は供用されている状態（以下，現況），つまり物 の除去作業後（以下，除去後），乳剂等による表面処理 後（以下，処理後），および一定期間経過後に行った.

\section{（2）機能回復方法}

機能回復は，つまり物の除去と表面処理によって行っ た.

表-1 施工箇所概要および使用材料

\begin{tabular}{|c|c|c|c|c|c|}
\hline $\begin{array}{c}\text { 路 面 } \\
\text { 処理方法 }\end{array}$ & 路楾名 & $\begin{array}{l}\text { 舗装 } \\
\text { 種別 }\end{array}$ & 供用期間 & $\begin{array}{c}\text { 表面 } \\
\text { 処理材 }\end{array}$ & $\begin{array}{l}\text { 施工 } \\
\text { 方法 }\end{array}$ \\
\hline 乳剂 A(1) & $\begin{array}{c}\mathrm{R} 10 \\
\text { (新富町) }\end{array}$ & \multirow{5}{*}{$\begin{array}{c}\text { 排 } \\
\text { 水 } \\
\text { 性 } \\
\text { 舗 } \\
\text { 装 } \\
13 \mathrm{~mm}\end{array}$} & 3 年 8 ケ月 & 乳剤 A & \multirow{3}{*}{ 塗布 } \\
\hline 乳剂 A(2) & \multirow{2}{*}{$\begin{array}{c}\mathrm{R} 10 \\
\text { (宮崎市) }\end{array}$} & & \multirow{2}{*}{1 年 11 ヶ月 } & 乳凮 $\mathrm{A}$ & \\
\hline 乳㶡 B & & & & 乳剤 B & \\
\hline 乳剤 C & \multirow{2}{*}{$\begin{array}{c}\mathrm{R} 6 \\
\text { (水戸市) }\end{array}$} & & 2 年 11 ヶ月 & 乳剈C & \multirow{2}{*}{ 散布 } \\
\hline 樹脂 & & & 2 年 11 ヶ月 & 樹脂 & \\
\hline
\end{tabular}

\begin{tabular}{|c|c|c|}
\hline 材料名 & 特徴 & 使用量 \\
\hline 乳凧 A & $\begin{array}{l}\text { 改質万スファ } \\
\text { カ我系 }\end{array}$ & 改質乳凧 $0.15 \mathrm{~kg} / \mathrm{m}^{2}$ \\
\hline 乳剂 B & $\begin{array}{l}\text { 改質「ス7ルト } \\
\text { 梿系 }\end{array}$ & 改質乳剤 $030 \mathrm{~kg} / \mathrm{m}^{2}$ \\
\hline 乳剤 C & 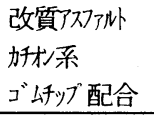 & $\begin{array}{l}\text { 改質乳剤 } 0.3+0.3+0.1 \mathrm{~kg} / \mathrm{m}^{2} \\
5 \text { 号珠砂 } 0.4 \mathrm{~kg} / \mathrm{m}^{2}\end{array}$ \\
\hline 樹脂 & 排水性用 & $\begin{array}{l}\text { トッブ コート用樹脂 } 0.5+0.5 \mathrm{~kg} / \mathrm{m}^{2} \\
\text { トップ コート用骨材 } 0.25+0.25 \mathrm{~kg} / \mathrm{m}^{2}\end{array}$ \\
\hline
\end{tabular}

\section{a) つまり物の除去}

空隙に詰まっている塵埃を取り除くことによって空隙 を確保し，騒音低減効果を回復させることを期待し，機 能回復機 1) を用い，5MPa の高圧水による洗浄後, 除去 物と水を吸引回収する，つまり物の除去作業を行った.

\section{b) 表面処理}

表面処理は，つまり物を除去した後，路面が充分乾燥 した状態で乳剤および樹脂を塗布，および散布して行っ た. 施工場所の概要, および使用した処理材を表-1, 使 用材料の詳細を表-2に示す.

\section{（3）機能回復の結果}

\section{a) タイヤ/路面騷音レベル}

除去後, および処理後のタイヤ/路面騒音レベルを 図-1に示す.

ここで，タイヤ/路面騷音レベルは普通タイヤを用い て測定しているため, 精度の高い測定は困難と判断し, 基淮路面を設け，その差で評価した.

これより騒音レベルが大きくなる場合があるものの， 除去後は乳剂 $\mathrm{C}$, 樹脂, 処理後は乳剤 $\mathrm{A}(1)$, 乳剤 $\mathrm{C}$, 樹 脂の路面て騷音レベルが低くなっている，表面処理につ いては，処理材を多く使用した乳剤 $\mathrm{C}$ と樹脂の路面に おいて，特に騷音レベルが低くなっていることから，機 能回復の可能性が示された.

追跡調查により，経時変化を確認した． 結果を図-2

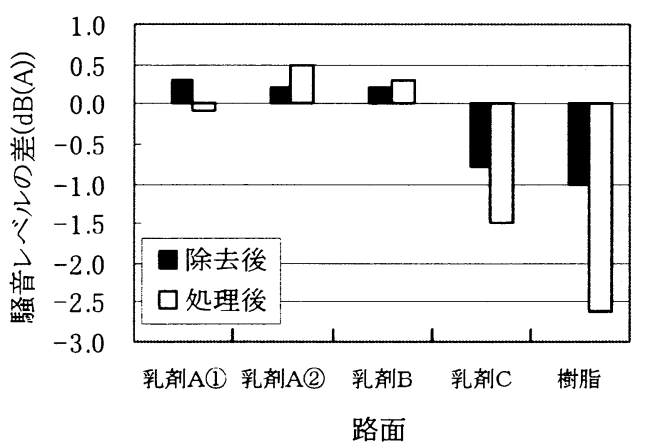

図-1 機能回復の効果（タイヤ/路面騷音）

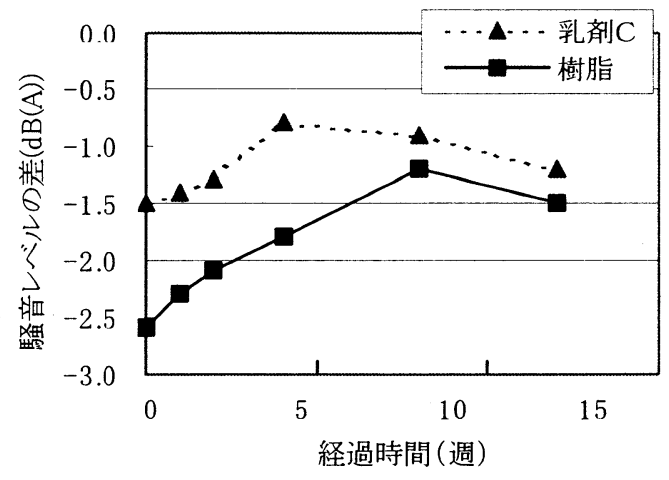

図-2 処理路面での騒音レベルの経時変化 
に示す．これより乳剤 $\mathrm{C}$ ，樹脂ともに，徐々に低减効果 は薄れ，8週程度で低減効果がほぼ一定值となる。

b) $M P D(S)^{5}$

各路面の MPD(S)を図-3 に示す．ここで，除去作業に よる MPD(S)の差はあまり明確ではない. しかし処理後 において乳剤 $\mathrm{C}$ は約 $0.2 \mathrm{~mm}$ 減少するのに対し，樹脂は 約 $0.1 \mathrm{~mm}$ 増加と両極端な状況を示す.

追跡調査により，すりへり量の検証を行った結果を，

図-4 に示す。これより乳剤 C はあまり大きく変化しな いのに対し，樹脂は時間とともに減少する傾向が見られ た.

\section{c) MPD (S) と騒音レベルに関する疑問}

乳剤 $C$ と樹脂は, 図-5 に示すように, MPD(S) とタイ ヤ/路面騒音は負の相関，つまりテクスチャが大きくな るほど騒音レベルは小さくなる傾向を示している. しか し従来, テクスチャとタイヤ/路面騒音については, 正 の相関が示されている ${ }^{4)}$. この事は, 従来の評価方法 とは異なった評価方法の必要性を示寸ものと考えた.

\section{4. テクスチャの評価方法}

機能回復作業における処理の前後では, テクスチャが 変化するものと想定される. またこれらの変化は, MPD で評価されるよりももっとミクロな領域である可 能性がある.

そのため, ミクロテクスチャの変化を評価する手法に ついて, 以下のように考えた.

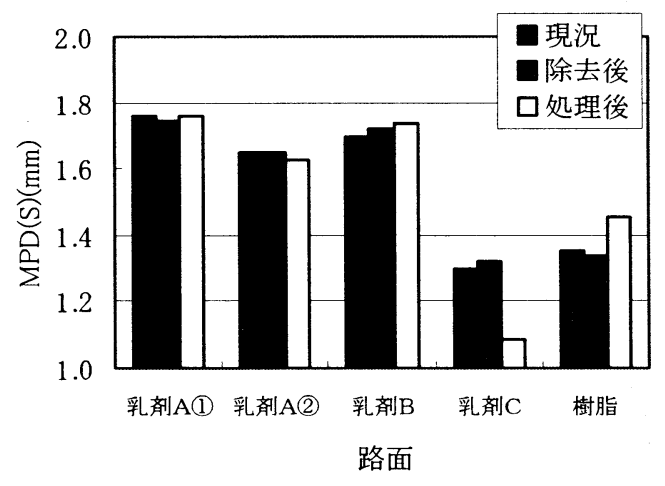

図-3 機能回復の効果 $(M P D(S))$

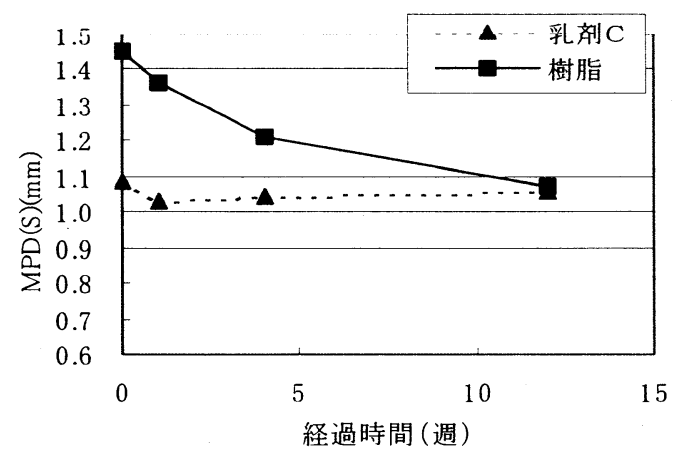

図-4 すりへり量の経時変化 $(\mathrm{MPD}(\mathrm{S}))$

\section{（1）評価方法の必要性}

MPD`は図-6，式（1）に示すように，基長区間の平均 と, 基長の半分の区間で最も凸となっている部分の差を, 左と右 ( $\left.\mathrm{H}_{\max } 1, \mathrm{H}_{\max 2}\right)$ で平均して求める.

$$
\begin{aligned}
& \mathrm{MPD}=\left(\mathrm{H}_{\mathrm{MAX}} 1+\mathrm{H}_{\mathrm{max}} 2\right) / 2-\mathrm{H}_{\text {MEAN }} \\
& \text { MPD : 平均プロファイル深さ } \\
& \mathrm{H}_{\text {MEAN }} \text { :平均レベル } \\
& \mathrm{H}_{\max } 1,2: 1,2 \text { 番目の最大レベル }
\end{aligned}
$$

表面処理後のテクスチャの評価対象は，一定期間が経 過した後のテクスチャである. テクスチャの変化を模式 的に図-7 に示す.ここで供用期間が長くなるにしたが い，テクスチャは以下のように変化すると考えられる.

(1) アスモルの消失による骨材表面の露出

(2)つまり物の堆積による, 空隙の消失 (空隙つまり)

(3) 空隙の縮小による沈下 (空隙つぶれ)

(4) テクスチャの変化しない領域 (不動区間) ただし，今回は空隙つぶれについては考慮しないもの

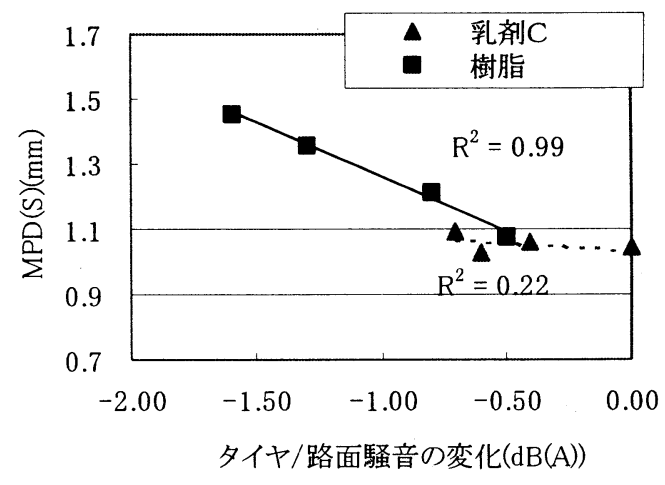

図-5 タイヤ/路面騒音レベルと MPD(S)の比較

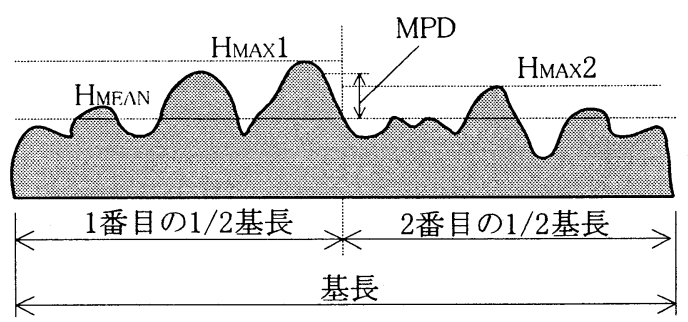

図一－MPD の概念 (参考文献 6 を基に作成)

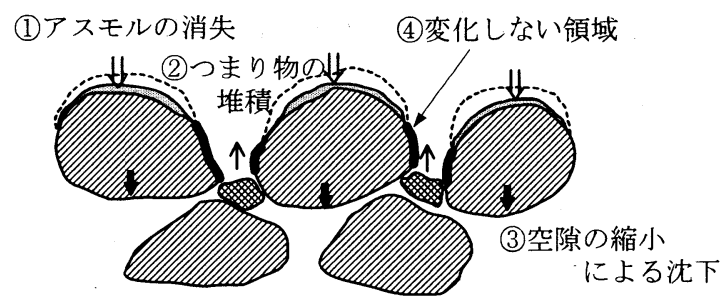

図-7 供用後の舗装表面の変化 
として，わだち掘れの発生していない箇所を対象に検討 を行った.

\section{(2) 解析の概念}

今まで提案されている方法では, 例えば追跡調査を行 う場合，1回目と2回目で同じ位置であることを確認す ることができない，そのため，以下の手順によって仮の 基準となる区間（以下，不動区間）を求め, 変化が生じ たと想定される前後の值を比較することによって，評価 を行えると考えた. 以下に考え方を示す.

(1) 図-8に現況の路面形状のモデル化した図を示す。こ こで，基長区間の最も高い位置を $\mathrm{H}$ max とし，そこ からの下がりを，大きい方から順番に左から右に 並べたグラフを整列形状とする。ここで，下がり の大きな位置は空隙の底部に位置するところであ ることから，Bottom 部，下がりの小さな位置は凸部 に位置するところであることから Top 部と記す。

(2) 図-7 のつまり物が堆積した状況と, 表面のアスモル が失われた状況のテクスチャをモデル化すると， 図-9 のように示すことができる. アスモルが失わ れた状態と空隙つまりの状態では，上の領域と下 の領域に変化が現れることは容易に推定できる.

しかし，現在提案されているテクスチャを評価す る手法においては，これらを区別することができ ない。

(3) 基長区間の最も高い位置 $\mathrm{H}$ MAx 基準として整列形 状を示すと，図-10 のようになる. しかし，ここで はどの部分が変化したかを知ることはできない. このような現象は，基準となる不動区間を特定で

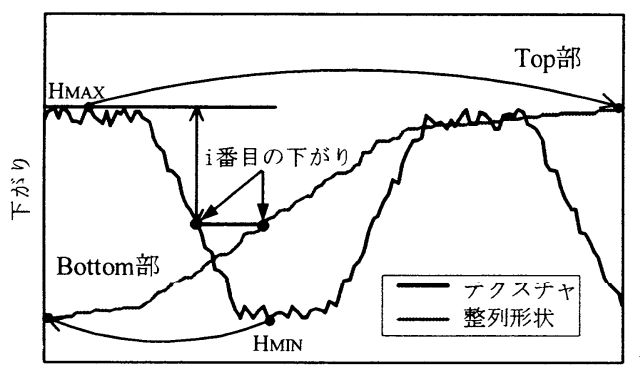

図-8 基長区間における路面形状と下がりの 整列形状のモデル

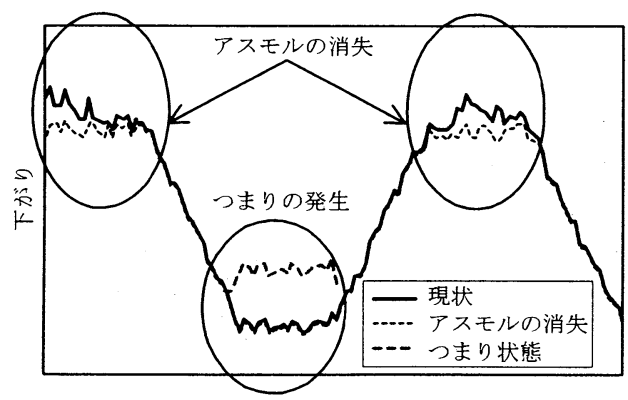

図-9＼cjkstart路面形状の変化のモデル
きないためと考えられる，そこで，ここでは中間 付近に位置する部分は変化しないものと推定でき ることから，その部分を重稀わせると，図-11 の ように示寸事ができる.ここで，Top部と Bottom部 付近においてテクスチャが変化し，その間は変化 がないことから，不動区間と想定される.

(4) 図-11 の不動区間は傾きを持つことから，より分か りやすくするため, 特定の整列形状を基準とし, その差（以下，整列形状差）を評価することとし た。その結果を図-12 に示す．これより，基準とし た整列形状に対して変化がない部分は，表面凹凸 の変化が一定の值，つまり $\mathrm{X}$ 軸に対して平行に示 される.したがって，上方向に変化した部分は増 加する形状，下方向に変化した部分は減少する形 状を示すものと想定される.

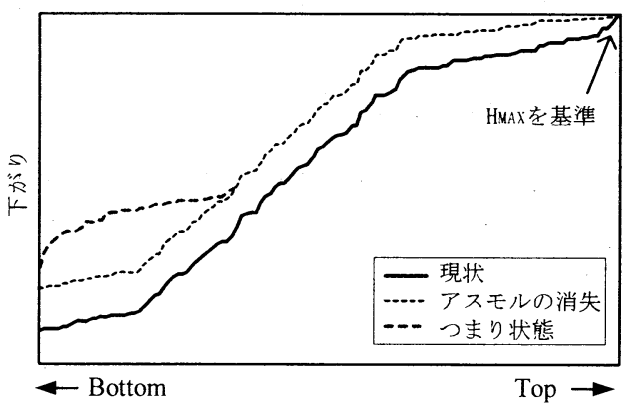

図-10 整列形状の変化のモデル(最高点を基準)

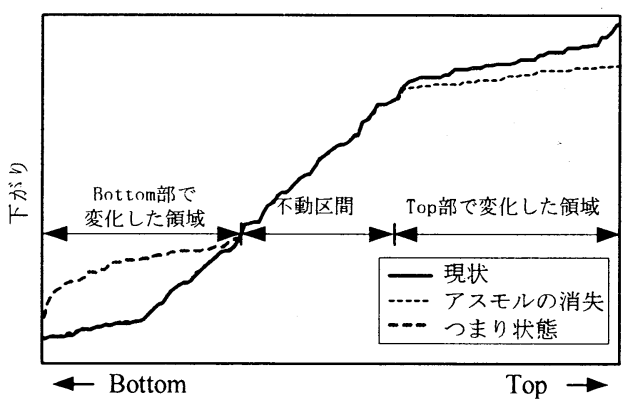

図-11 整列形状の変化のモデル(不動区間を想定)

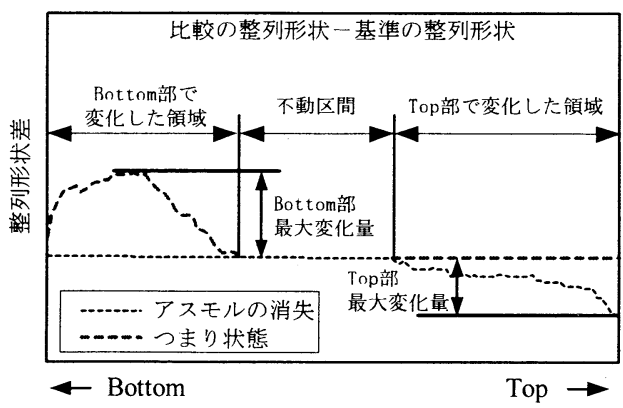

図-12 整列形状差のモデル 


\section{5. 評価手法の確認}

本手法によって評価が可能である事を確認するため, 表面性状が異なると考えられる舗装面を対象にデータを 採取し，不動区間に対する考え方についての検証を行っ た.

対象とした排水性舗装は，図-13 に示寸ように，不動 区間が想定される路面と不動区間がないと想定される路 面であり，どのような路面であれば本手法の適用が可能 かについても評価を行った。

\section{（1）つまり物除去作業}

つまり物を取り除く除去作業においては，表面のアス モルなどに対する影響はないことから，空陌が詰まって いる箇所以外は不動区間になると想定した. 作業後の整 列形状の值から，現状の整列形状の值を引いた值を 図-14 に示す.これより，予想どおり不動区間の存在す ることが確認できた。

\section{（2）表面にアスファルト乳剤を塗布した路面}

今回調査を行った表-1 の乳剂 A(1)，A(2)，Bにおいて は, 除去後, 次の日に表面処理を行っている. この時乳 鼡は，塗布したことから，その表面性状は写真-1 に示 すように，表面にだけ乳剤が付着しており，それ以外の 骨材部分は露出している事から，不動区間を有すると考 えられる. 処理後の整列形状の值から, 除去後の整列形 状の值を引いた結果を図-15に示す.

これより，推定どおり不動区間の存在することが確認 できた.

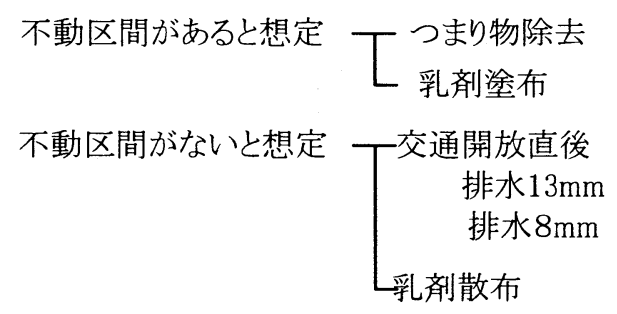

図-13 解析の対象とした路面

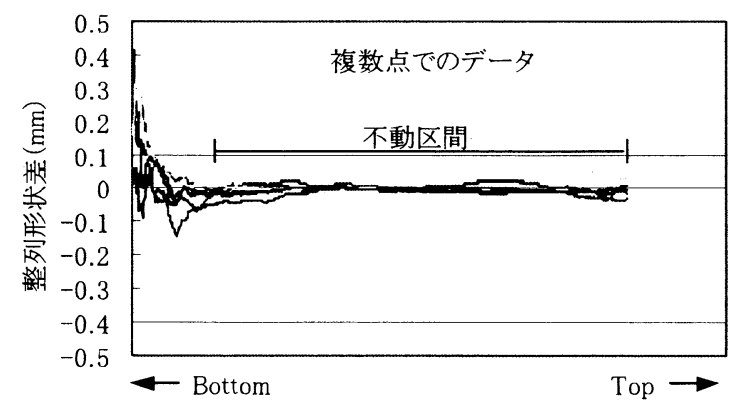

図-14 除去作業による路面の変化

\section{（3）新設排水性 $13 \mathrm{~mm}$}

アスファルト混合物のわだちは，交通開放直後に初期 わだちが発生しやすい．この時骨材は，タイヤによるニ 一ディング作用によって, 垂直に沈下するのではなく, こねるように，骨材に回転が加わって動くものと想定さ れることから，不動区間はない可能性があると考えた.

交通開放後 7 週間の整列形状の值から, 開放前の值を 引いた值図-16 に示す。これより，予想に反し不動区間 の存在することが確認できた.

\section{（4）新設排水性 $8 \mathrm{~mm}$}

新設排水性 $13 \mathrm{~mm}$ と同様, 最大骨材粒径の小さな $8 \mathrm{~mm}$ であっても, 交通開放直後には骨材全体が動くも のと想定された. 交通開放後 2 週間の整列形状の値から， 開放前の值を引いた值を図-17 に示すここれより排水 $13 \mathrm{~mm}$ と同様, 不動区間の存在する事が確認できた。

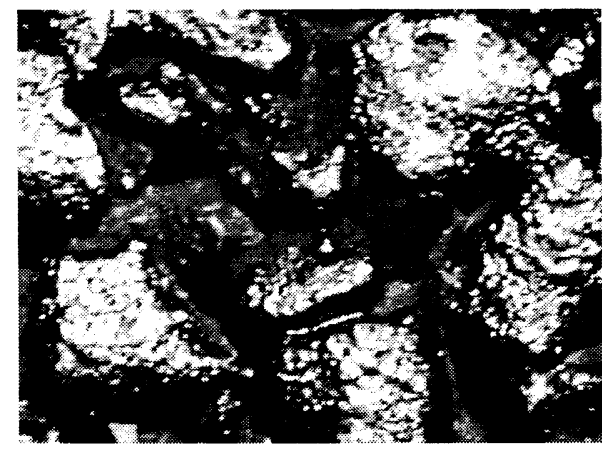

写真-1 乳剤除布後の表面性状 (白く光っている部分が乳剂)

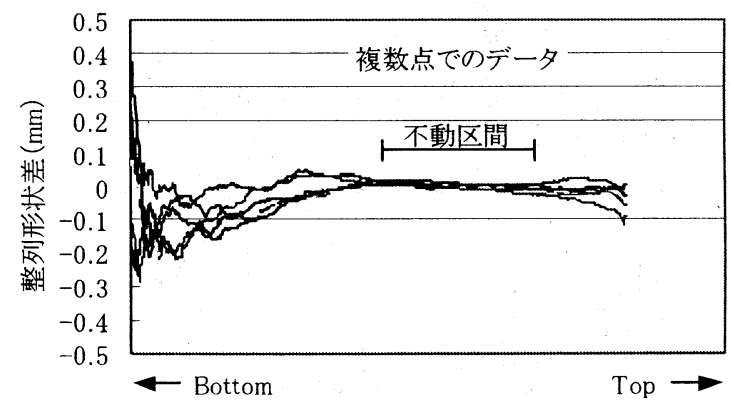

図-15 乳剤塗布による路面の変化

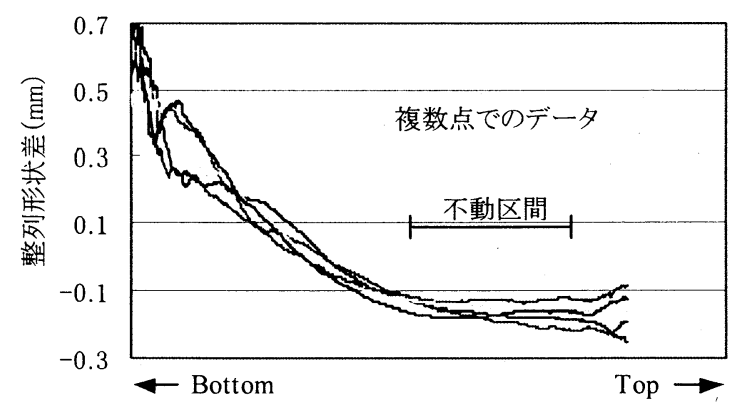

図-16 新設時の変化 最大骨材粒径 $13 \mathrm{~mm}$ 


\section{（5）表面に乳剤を散布した路面}

表-1 の乳剤 C に対応する. アスファルト乳剤を塗布 した場合に比べ，散布した場合には，写真-2 に示すよ うに表面だけではなく，空隙の中にまで乳剤の付着が確 認されることから，不動区間の存在しない事が想定され た.

処理後の整列形状の值から，除去後の整列形状の值を 引いた值を図-18 に示す。これより全区間に渡り，平行 な形状がないことから，不動区間のないことが明らかと なった.

また散布後にも追跡調査を行っているため，不動区間 についての確認を行った. 現況を基準とした整列形状と の差を図-19 に示す．これより，処理後以降の形状が似 ていることから，現状を基準とするのではなく，3 3 月 の追跡調查は 1 ヶ月を基準というように，前回調査との 整列形状の差を求めた. その結果, 図-20 に示すように, 処理直後には不動区間が見られないものの，それ以外に

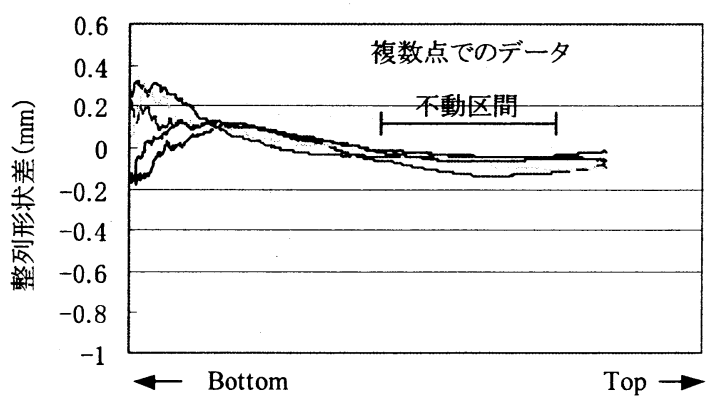

図-17 新設時の変化 最大骨材粒径 $8 \mathrm{~mm}$

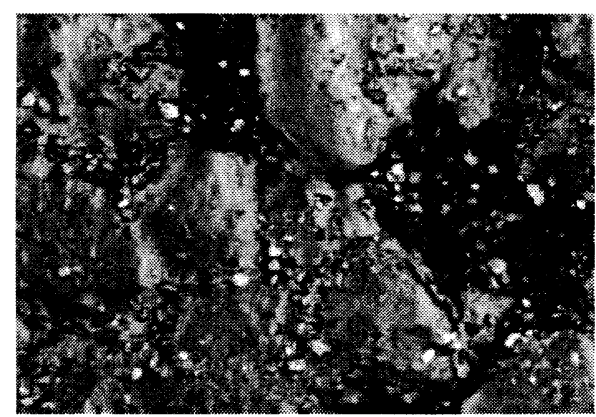

写真-2 乳剂処理後の表面性状

（黒い空隙を除き，全体的に乳剂の存在が確認できる）

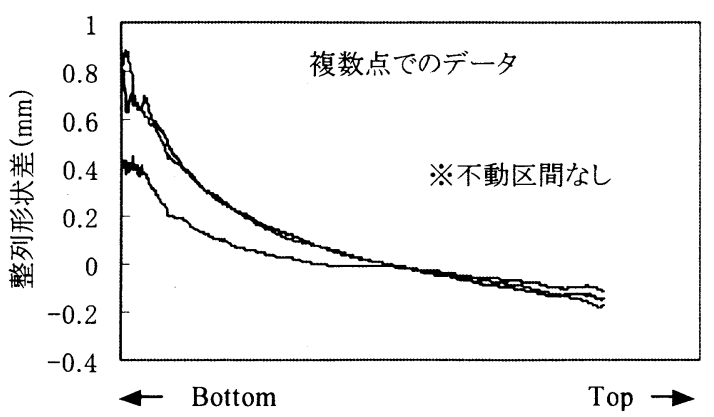

図-18 乳剤散布後の変化
は不動区間が存在する，従って，乳剂散布のように表面 のテクスチャの状態が大きく変化する場合でない限り, 不動区間のあることが確認できた.

\section{（6）適用限界について}

以上の検討の結果，路面全体に乳剂を散布した場合を 除き，不動区間の存在する事が確認できた．ただし，乳 剤を散布した場合であっても，その後の追跡調査時は不 動区間が存在することから，極端に大きなテクスチャの 変化がない限り, 不動区間は存在する事が確認できた.

\section{6. 樹脂散布作業に対する評価}

MPD とタイヤ/路面騷音に負の相関を示した，樹脂を 散布した工区について，不動区間を考慮した評価を試み た. さらに，その結果に基づき，滑りとの関係について も評価を行った。

\section{（1）表面に樹脂を散布した路面の評価}

処理後の整列形状の值から，除去後の整列形状の值を 引いた值を，図-21 に示す。これより，不動区間の存在 することが確認できる.さらに処理後以降にも不動区間 があることを確認するため，乳剂散布と同様，前回調査 との整列形状の差を求めた，その結果，図-22 に示すよ うに，不動区間が確認できる.

そこで図-12 に示すように，変化の大きな Top 部と

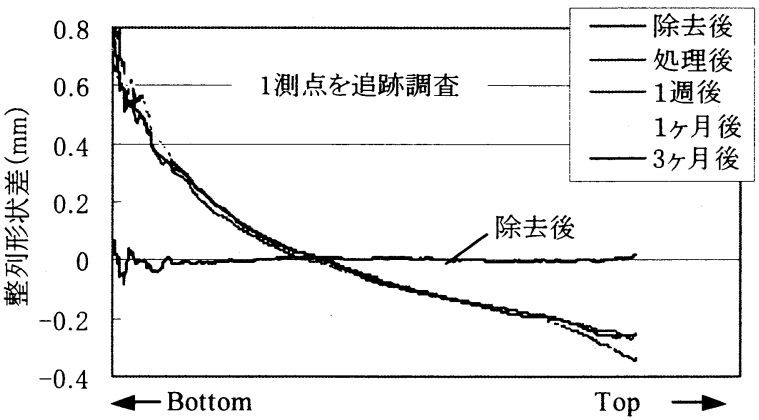

図-19 乳剂散布による整列形状差の変化 (現況を基準)

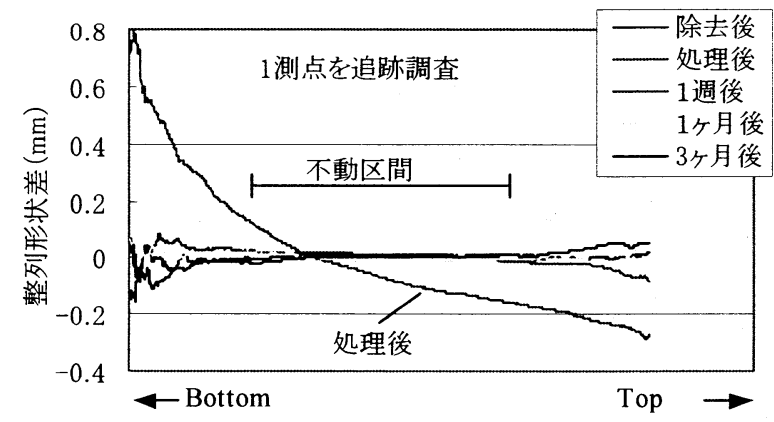

図-20 乳剂散布による整列形状差の変化 (前回調査からの変化) 
Bottom 部を対象に，不動区間と最も変化の大きい位置と の差 (以下, 最大変化量) を求め, さらに処理後からの 変化を求めるため, 処理直後から 3 ケ月経過後までの最 大変化量を累積 (以下，累積最大変化量）し，タイヤ 路面騒音レベルとの相関を求めた．その結果を図-23 に 示す.これより, Bottom 部は相関が認められないものの, Top 部を対象とした相関係数は 0.89 と高い事から, 表面 部の変化がタイヤ/路面騒音レベルに大きく寄与してい る事が確認できた.

\section{（2）表面部の変化と滑り抵抗との関係}

前述の検討の結果, 表面部の変化がタイヤ/路面騒音 の変化に強く関与しており, なおかつ表面の累積最大変 化量が大きいほど，騒音レベルの低下することが確認で きた.このように，ミクロテクスチャに注目した場合に，

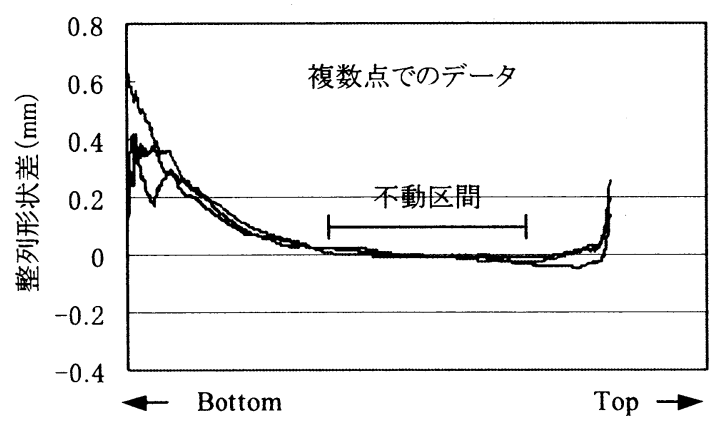

図-21 樹脂散布後の変化

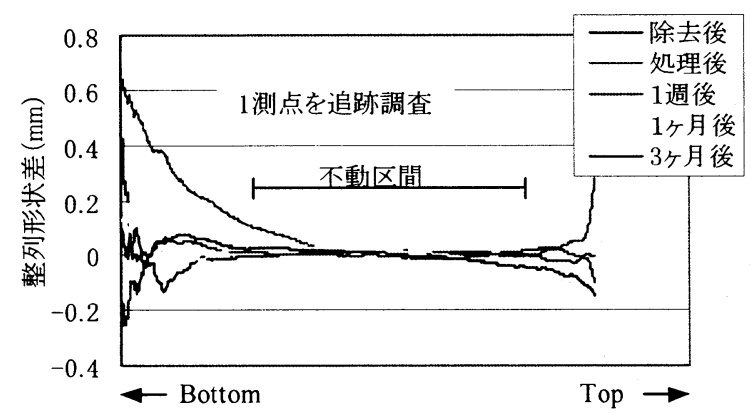

図-22 樹脂処理による整列形状差の変化 （前回調査からの変化）

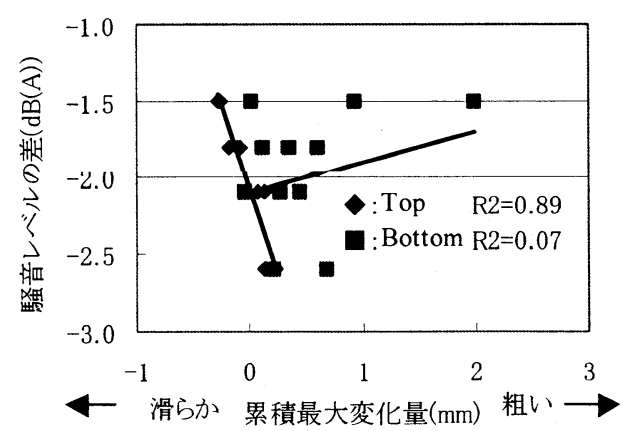

図-23 樹脂処理
表面が粗いほどタイヤ/路面騒音が低下する現象の原因 としては，図-24 に示すように，タイヤトレッドブロッ クが路面をすべる（Stick-Slip という）時に生じる摩擦音 力が，路面粗さの減少により増加するためと考えられる. そこで，3測点のデータにより, 滑りと累積最大変化量 の関倸についての評価を行った，滑りは，DFテスター を用いて測定し, 動的摩擦係数として求めた. その結果, 3 ヶ月後にほぼ 0.4 近くまで低下したものの, 以降, 向 上する傾向を示している.

動的摩擦係数と累積最大変化量との関係を図-25に示 す.これより，0.82〜0.95 と高い相関が見られた.この 傾向は，40km/ を想定した RSN-40km も同様であった.

上述したように, 表面の累積最大変化量が大きいほど タイヤ/路面騒音が小さくなる現象は，滑りと密接に関 係しており，Stick-Slipによると考えられる.

ここで， 3 測点ともに相関が高いのに対し傾きや切片 が異なるのは，不動区間という，相対的な基準点を設け たため，すべてのデータを絶対的な值として比較できな いためである.

\section{7. 結論および課題}

以上の研究より, テクスチャの評価について, 以下の 結論が得られた。

・表面形状をミクロテクスチャで評価した場合，テク スチャの状態が変化しない領域（不動区間）が存在 することが確認できた。

・不動区間を基準として, ミクロテクスチャの形状に

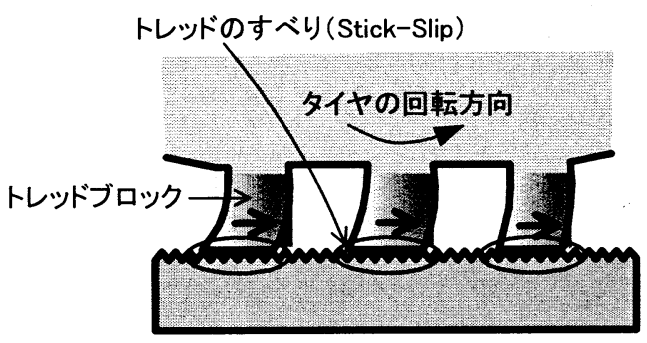

図-24 Stick-Slip の模式図（参考文献 7 を基に作成）

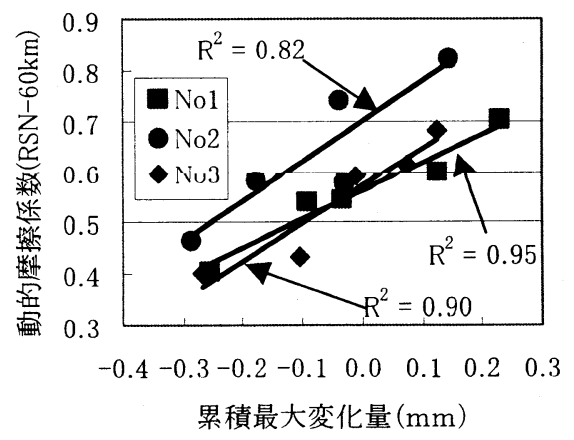

図-25 最大变化量と動的摩擦係数との関係 
着目する事によって, テクスチャのどの部分が変化 したのかを評価できる可能性がある.

・ただし評価はあくまでも相対的なものであり，それ 以降の検証が必要である.

・ タイヤ/路面騒音とテクスチャは, 高い相関が認め られた. 同時に動摩擦係数との間にも高い相関が認 められたことから，トレッドブロックのすべり音の 発生要因である Stick-Slipがタイヤ路面騷音と密接に 関係していることが推定できた.

- 今回の研究において「騒音低減効果の回復」と「テ クスチャの評価」に関して，一定の成果を得た。し かし現場での検証が必要な事から, デー夕数が充分 とはいえない.したがって，今後はデー夕数を増や し, 更なる研究を進めていく事が必要と考える.

\section{8. おわりに}

騒音低減効果の回復を目的に表面処理を行い，その有 効性を確認する事ができた. 同時に, テクスチャ評価に 対する新しい手法を用いる事により，従来とは異なり Stick-Slipの卓越した現象を評価する事ができた.

これらの貴重なデータを得ることができたのは，検証 のための現場を提供してくださいました, 久保所長（現 独立行政法人土木研究所上席研究員）をはじめとした宮 崎河川国道事務所の方々，および池田課長をはじめとし た常陸河川国道事務所, 菊池所長 (現宇都宮国道事務所 管理 2課長）をはじめとした同水戸出張所の方々の御尽
おによるものである事を記し，心から感謝する次第です．

\section{参考文献}

1）増山幸衛, 草刈憲嗣 : 排水性舗装の機能回復作業の方向性, 舗装, pp26-32, 2003. 11.

2）酒井雅利, 池田一壽, 戸倉健司 : 低騒音舖装の機能低下と維 持清掃作業に関する検討, 舖装, pp29, 2002. 11.

3）増山幸衛, 片山潤之介, 草刈憲嗣, 岩井茂雄, 寺田 剛: 解析方 法の違いを考慮したテクスチャの評価に関する研究，土木 学会舗装工学論文集, 第 9 巻, pp231-238, 2004. 12.

4）井原務, 石垣勉, 井上武美: 排水性舗装の路面テクスチャ とタイヤ/路面騒音に関する検討，土木学会舖装工学論文集， 第 7集, pp. 1-1-1-6, 2002.

5）橋本喜正, 新田弘之, 吉田武 : 路面性状からのタイヤ/路面 騒音の予測に関する検討，土木学会舗装工学論文集，第 7 集, pp2-1-2-9, 2002.

6) Characterization of pavement texture by use of surface profiles-Part2: terminology and basic requirements related to pavement texture profile analysis, DRAFT INIERNATIONAL STABDARD ISO/DIS 13473-2, 1999.

7) Ulf Sandberg, Jerzy A. Ejsmont:TYRE ROAD NOISE REFERENCE BOOK, Part of the picture reproduced with permission by Continental Gislaved Dack AB, 2002.4.

\title{
A PROPOSAL ON THE EVALUATION METHOD OF MICRO-TEXTURE OF POROUS PAVEMENT
}

Yukiei Masuyama, Junnosuke Katayama, Noritsugu Kusakari and Shigeo Iwai

\begin{abstract}
An increase of tire/road noise level was measured as the surface roughness of porous pavement decreases under its surface treatment. The new surface evaluation method by micro-texture based on wearing out of asphalt-mortar and clogging condition is proposed assuming nonmovement of the coarse aggregates. The result of the texture analysis shown the existence of the non-movement duration of the aggregates, then it is confirmed that the proposed method can evaluate the changes of micro-texture and that an adequate correlation between the changes of microtexture and the dynamic friction coefficient. And then, it is estimated that the increase of tre/road noise level after surtace treatment is generated by the stick-slip phenomena of tire tread block.
\end{abstract}

